\title{
Restorative role of Deprenyl on Mitochondrial function of aging rat cerebellum
}

\author{
Manju .V. Subramanian* and James T.J \\ Division of Neurobiology and Ageing, Department of Zoology, Sacred Heart College, Cochin - 682013, India.
}

\begin{abstract}
Mitochondria are known to be a rich source for the production of free radicals and, consequently, mitochondrial components are susceptible to lipid peroxidation that decreases respiratory activity. The present investigation was designed to evaluate the neuroprotective effect of Deprenyl on mitochondrial function in rats with respect to changes in the mitochondrial energy status. Intraperitoneal administration of liquid deprenyl $(2$ $\mathrm{mg} / \mathrm{kg}$ body weight/day for a period of 15 days i.p, significantly $P<0.05)$ to the experimental rats of three age groups (6, 12 \&18 months old) prevented the age related reduction in Tricarboxylic acid cycle enzymes [isocitrate dehydrogenase, $\alpha$-ketoglutarate dehydrogenase, succinate dehydrogenase and malate dehydrogenase] and respiratory marker enzymes [NADH dehydrogenase and cytochrome-c-oxidase] in the cerebellar mitochondria. The results of the present study indicate that the overall neuroprotective effect of deprenyl is probably related to its ability to retain the energy status of cerebellum by preserving the activities of Tricarboxylic acid cycle enzymes and respiratory marker enzymes at near normalcy and/or to its free radicalscavenging capability against age related aberrations in lipid peroxidation, which is responsible for unalterable changes in neuronal membrane.
\end{abstract}

Key words: deprenyl, tricarboxylic acid cycle enzyme, respiratory marker enzymes, mitochondria, cerebellum

\section{Introduction:}

Mitochondria are the most important intracellular source and target of reactive oxygen species. Mitochondrial aging is characterized by destruction of structural integrity of the membrane, leading to a decline in mitochondrial membrane fluidity and activities of enzymes associated with membrane lipids [1]. As the activities of most enzymes are regulated by the physicochemical state of the lipid environment of the membrane, it seems likely that impaired mitochondrial membrane function brought about by aging could be related to a decrease in membrane fluidity due to free radical reactions such as lipid peroxidation. ROS and their metabolites are generated by components of electron transport chain in the membrane during mitochondrial respiration. This potential for self-destruction renders the mitochondrial membrane, more vulnerable to oxidative damage than other cellular membranes. ROS generated by mitochondria can cause damage to mitochondrial components and initiate degenerative processes $[2,3]$.<smiles>C#CCN(C)C(C)Cc1ccccc1</smiles>

Fig 1: Chemical structure of deprenyl

Deprenyl,(N-methyl-N-(1-methyl-2-phenyl-ethyl)-prop-2-yn-1-amine) (Fig: 1) has been shown to increase neuronal survival and to alter protein synthesis. Certain drugs like encephabol, chloropromazine, kavain and centrophenoxine [4] and ayurvedic formulations like Geri forte, ceflatone and amrithkalash [5] have also been claimed to have the same lipofusciolytic effect. Deprenyl has a wide range of pharmacological properties that are beneficial in the treatment of human neuro-degenerative disease. The findings suggest that long term usage of deprenyl can slow down the aging process itself, the brains output of dopamine declines $13 \%$ per decade after the age of 45 and Deprenyl protects the brains dopamine producing brain cells from destruction and also, the neurons (brain cells) that use dopamine are the most rapidly aging neurons in the human brain [6]. No single drug or remedy has not yet been identified to revert or delay aging or at the most to have a healthy aging.

By inducing antioxidant enzymes and decreasing the formation of reactive oxygen species, deprenyl is able to combat an oxidative challenge implicated as a common causative factor in neurodegenerative diseases. Deprenyl requires metabolic conversion to a hitherto unidentified metabolite to exert its antiapoptotic effect, which serves to protect the integrity of the mitochondrion by inducing transcriptional and translational changes. 
Pharmacokinetic and metabolism studies have revealed that deprenyl undergoes intensive first pass metabolism, and its major metabolites also possess pharmacological activities [7].

However, deprenyl has a wide range of pharmacological properties, the protective effect of deprenyl on TCA cycle enzymes andrespiratory marker enzymes in cerebellum with age have not been explored. The cerebellum seems to be affected by age [8] although its volume loss is less as compared to the cerebrum. Since the cerebellum is a vital organ for the postural control, equilibrium and motor coordination, in the present study, an attempt has been made to assess the protective effects of deprenyl administration against age associated alterations in the levels of TCA cycle enzymes and respiratory marker enzymes in rat cerebellum. Because of its stereotyped and strikingly beautiful organization the cerebellum is an excellent model in which to explore the age-related pathological alterations.

\title{
Chemicals
}

\section{Materials and methods}

Deprenyl was procured from International Antiaging SystemsPO Box 6, Sark GY9 0SB, United Kingdom. All the other chemicals used were of analytical grade.

\begin{abstract}
Animals
Adult male Wistar strain albino rats 350-380g (6 months); 370-400g (12months); 390-420g (18 months) were selected for the study. The animals were housed individually in polypropylene cages under hygienic conditions and maintained at room temperature of $28 \pm 2^{\circ} \mathrm{C}$; relative humidity of $60-70 \%$; $12 \mathrm{~h}$ light-/dark cycle. The animals were maintained on standard pellet diet supplied by M/S Sai feeds, Banglore and water ad libitum. The experiment was carried out as per the guidelines of Committee for the Purpose of Control and Supervision of Experiments on Animals (CPCSEA), New Delhi, India.
\end{abstract}

\section{Experimental protocol}

Five days after acclimatization, the animals were divided into six groups of 6 rats each. Three categories of male rats; 6 months old, 12 months old and 18 months old were used for the experiment. Group Ia, normal control rats of 6 month old received only the standard diet. Group Ib, 6 month old rats intraperitoneally (i.p) injected with liquid Deprenyl $2 \mathrm{mg} / \mathrm{kg}$ body weight for 15 days. Group IIa, normal rats of 12 month old received only the standard diet. Group IIb, 12 months old rats intraperitoneally (i.p) injected with liquid Deprenyl $2 \mathrm{mg} / \mathrm{kg}$ body weight for 15 days. Group IIIa, normal control rats of 18 months old received only the standard diet. Group IIIb, 18 months old rats intraperitoneally (i.p) injected with liquid Deprenyl $2 \mathrm{mg} / \mathrm{kg}$ body weight/day for 15 days. Control animals (Group Ia, IIa and IIIa) were intraperitoneally injected with physiological saline alone for 15 days.

At the end of the experiment, i.e. $24 \mathrm{~h}$ after the last injection of deprenyl, the experimental rats were killed. The whole brain was removed by opening the cranium and cerebellum was excised carefully. One portion of the tissue was fixed in buffered formalin for histological studies. Accurately weighed cerebellum was homogenised in ice-cold 0.1M TrisHCl buffer and centrifuged. Mitochondrial fractions of cerebellar tissue were isolated by the method of Plummer [9] were used for the determination of TCA cycle enzymes [isocitrate dehydrogenase (ICDH) (EC 1.1.1.42), -ketoglutarate dehydrogenase $(\alpha-\mathrm{KDH})$ (EC 1.2.4.2), succinate dehydrogenase (SDH) (EC 1.3.99.1) and malate dehydrogenase (MDH) (EC 1.1.1.37)], respiratory marker enzymes [NADH dehydrogenase (EC 1.6.99.3) and cytochrome-c-oxidase (EC 1.9.3.1)].

\section{Biochemical analysis and enzyme assays}

ICDH activity was assayed according to the method of Bell \& Baron (1960) [10]. Briefly, the reaction mixture consisting of $0.1 \mathrm{M}$ Tris-HCL buffer, $0.1 \mathrm{M}$ trisodfumisocitrate, $0.015 \mathrm{M}$ manganous chloride, $0.001 \mathrm{M}$ NADP and mitochondrial suspension was incubated at $37.0^{\circ}$ for $60 \mathrm{~min}$. Added to this were $1.0 \mathrm{ml}$ of $0.001 \mathrm{M}$ DNPH and $0.5 \mathrm{ml}$ of 5\% EDTA. After $20 \mathrm{~min}$ incubation, $10 \mathrm{ml}$ of $0.4 \mathrm{~N} \mathrm{NaOH}$ was added and the colour intensity was measured at $390 \mathrm{~nm}$ in a Shimadzu- UV-1601 spectrometer. The activity of ICDH was expressed as $\mu \mathrm{mol} \alpha$-ketoglutarate liberated/min per mg protein.

SDH activity was estimated according to the method of Slater \& Bonner (1952) [11]. The rate of reduction of potassium ferricyanide was measured in the presence of sufficient potassium cyanide to inhibit cytochrome oxidase by following the rate of decrease in the optical density at $420 \mathrm{~nm}$. Briefly, $0.2 \mathrm{ml}$ of mitochondrial suspension was added to a reaction mixture containing $0.3 \mathrm{M}$ Phosphate buffer, 0.03 M EDTA, $0.4 \mathrm{M}$ Sodium succinate, $0.075 \mathrm{M}$ potassium ferricyanide, bovine serum albumin and $0.03 \mathrm{M}$ Potassium cyanide. The activity of SDH was expressed as $\mu$ moles of succinate oxidized/ min per mg protein.

Malate dehydrogenase activity was assayed by the method of Mehleret al. (1948) [12]. The activity determination is based on the measurement of the rate of oxidation of NADH in the presence of the enzyme and excess of oxaloacetate. Briefly, $0.3 \mathrm{ml}$ of $0.25 \mathrm{M}$ Tris- $\mathrm{HCl}$ buffer, $0.1 \mathrm{ml}$ of $\mathrm{NADH}$, and $0.1 \mathrm{ml}$ of oxaloacetate 
were added and the total volume was made to $2.9 \mathrm{ml}$ with water. The reaction was started by adding $0.1 \mathrm{ml}$ of mitochondrial suspension. The enzyme activity was measured at $420 \mathrm{~nm}$ in a Shimadzu- UV-1601 spectrophotometer using UV PC Software package. The activity of malate dehydrogenase was expressed as $\mu$ moles NADH oxidized/min per mg of protein.

NADH dehydrogenase activity was assayed according to the method of Minakamiet al. (1962) [13]. The reaction mixture contained $1.0 \mathrm{ml}$ of $0.1 \mathrm{M}$ phosphate buffer, $0.1 \mathrm{ml}$ of $0.03 \mathrm{M}$ potasiumferricyanide, $0.1 \mathrm{ml}$ of $0.1 \% \mathrm{NADH}$, and $1.6 \mathrm{ml}$ of distilled water in a total volume of $3.0 \mathrm{ml}$. The temperature was brought to $30^{\circ} \mathrm{C}$ and $0.1 \% \mathrm{NADH}$ was added just before the addition of the sample. A suitable aliquot of mitochondrial solution was added and the enzyme activity was measured at 420nm in a Shimadzu- UV-1601 spectrophotometer using UV PC Software package. The activity of NADH dehydrogenase was expressed as $\mu$ moles NADH oxidized/min per mg of protein.

$\alpha-\mathrm{KDH}$ activity was estimated according to the method of Reed \& Mukherjee (1969) [14]. It is based on the calorimetric determination of ferrocyanide produced by the decarboxylation of $\alpha$-ketoglutarate with ferricyanide as electron acceptor. To $0.15 \mathrm{ml}$ of $0.1 \mathrm{M}$ phosphate buffer, $0.1 \mathrm{ml}$ each of $0.002 \mathrm{M}$ thiamine pyrophosphate, $0.003 \mathrm{M}$ magnesium sulphate, and $0.01 \mathrm{M}$ potassium ferrocyanide was added. The total volume was made up to $1.2 \mathrm{ml}$ with water. Mitochondrial suspension $0.2 \mathrm{ml}$ was added and $30^{\circ} \mathrm{C}$ for $30 \mathrm{~min}$. Aliquots of the supernatant after centrifugation were taken, $0.1 \mathrm{ml}$ of $0.25 \mathrm{M}$ potassium ferricyanide was added, and the volume was made up to $2.4 \mathrm{ml}$ with water. One millilitre of $4 \%$ dupanol and $0.5 \mathrm{ml}$ of ferric ammonium sulphatedupanol reagent were added and incubated at $25^{\circ} \mathrm{C}$ for $30 \mathrm{~min}$. The colour intensity was measured at $540 \mathrm{~nm}$ in a Shimadzu UV-1601 spectrophotometer. The activity of $\alpha-\mathrm{KDH}$ was expressed as nanomoles of potassium ferrocyanide liberated/min per mg protein.

Cytochrome- $C$-oxidase activity was assayed according to the method of Pearl et al [15]. The enzyme activity was determined itilizing the accumulation of the free radical formed by the enzymatic univalent oxidation of a stable non-toxic substrate, $N$-phenyle- $p$-phenylenediamine. The reaction mixture consisted of $1.0 \mathrm{ml}$ of buffer, $0.2 \mathrm{ml}$ of $0.2 \%$ solution of $N$-phenyle-p-phenylenediamine, $0.1 \mathrm{ml}$ of cytochrome solution, and $0.5 \mathrm{ml}$ of distilled water. The reaction mixture was incubated at $25^{\circ} \mathrm{C}$ for $5 \mathrm{~min}$. Then added $0.2 \mathrm{ml}$ of the enzyme preparation was added and the solution mixed well by inverting the cuvette. A blank containing all the reagents except cytochrome-C, were also treated similarly. The change in optical density was measured in Shimadzu UV1601 spectrophotometer at 550nm at interval of $15 \mathrm{~s}$ for $5 \mathrm{~min}$. The activity of the enzyme was expressed as change in optical density/min per mg protein.

For fluorescent microscope studies, the separated cerebella were fixed in $10 \%$ buffered formalin for 24 hours, washed, dehydrated in ascending ethanolic series, cleared in xylene and embedded in paraffin wax. Care was taken that cerebella of individual animals were identically processed and left the tissue for equal times in the fixatives, alcoholic grades, xylene and paraffin. Serial sections were cut at 5 microns thickness on a Weswox Rotary Microtome. The sections were mounted on microslides (Delux; Blue Star) which were consecutively numbered, so that each section could be numbered from the beginning to the end. The deparaffinised and unstained sections were studied under the Olympus BX 51 fluorescent microscope equipped with a monochromatic camera (Evolution VF, Media Cybernetics Inc, MD, USA). Images were processed using the "Image pro-express" software (Media cybernetics Inc, MD, USA). The fluorescent pigment stood out sharply against the cytoplasm. Quantification of images was done with image analyzing software, Image J $1.42 \mathrm{~m}$. The area of both neuron and pigment was measured by using the software.

Statistical analysis

Results are expressed as mean \pm standard deviation (SD) for six animals and significant differences between mean values were analyzed using ANOVA with the aid of SPSS 10.0 for Windows. Duncan Multiple Range Test was done and $P<0.05$ was considered as statistically significant.

\section{Results}

Table 1 shows the activities of TCA cycle enzymes (ICDH, $\alpha-\mathrm{KDH}, \mathrm{SDH}$ and $\mathrm{MDH}$ ) and respiratory marker enzymes (NADH dehydrogenase and cytochrome-c-oxidase) in cerebellar mitochondria of normal and experimental groups of rats. A significant $(p<0.05)$ decline was noticed in activities of TCA cycle enzymes in the cerebellum of aged control (Group IIa and IIIa) compared to that of young control (Group Ia). In the present study, administration of deprenyl (Group Ib, IIb and IIIb)resulted in the maintenance of these mitochondrial enzyme activities at near normalcy as compared with those of the aged control groups.

Flurorescent microscopic analysis of cerebellum revealed that autofluorescence of the age-pigment, an end product of lipid peroxidation also varied in the different experimental as well as control groups of cerebellum. Lipofuscin or age pigment of purkinje neurons in young animal (Group Ia) preparations generally emitted a bluish-white fluorescence (Fig 1). The cerebella of aged (Group IIa and IIIa) animals were dominated by the pigment aggregations which emitted a golden-yellow halo (Fig 3 and 5). In the treated groups (Group Ib, $\mathrm{IIb}, \mathrm{IIIb})$, though retained the golden yellow fluorescence, harboured less pigment (Fig 2, 4, 6) than the control 
groups. Here, the pigment was generally found loosely and freely scattered in the cytoplasm. Though a large number of pigment granules and duplexes were present in the cerebella of treated group animals emitting a bluish-white and /or greenish-yellow pigment granules, they were rarely found in close vicinity of pigment aggregations or at or nearly the site where they get coalesced. Such pigment granules were rather scattered throughout the other area of the cytoplasm (Fig 4 and 6).

Pigment aggregations, whenever encounted in the Deprenyl treated group animals, presented, by and large, a loose texture as if they were tending to coalesce or drifting apart from one another (Fig 2, 4 and 6). Most of these lipofuscin granules emitted a yellow or golden-yellow fluorescence. Moreover, the amount of lipofuscin in purkinje neurons of the drug-treated preparations of Group IIIb(Fig 2, 4 and 6) was considerably less than that of the group IIb. The purkinje neurons of Group IIIa(Fig 5) preparations showed a greater amount of pigment than that seen in the cerebella of other control groups. The neuronal area of purkinje neurons and area of pigment accumulated of various control Group Ia, IIa and IIIa and experimental groups Ib, IIb and IIIb are given in the Table 2. There was a considerable increase in the quantity of pigment with age (Fig1, 3 and 5) and being significant $(\mathrm{p}<0.05)$. In deprenyl treated groups Ib, IIb and IIIb there occurs a significant $(\mathrm{p}<0.05)$ decrease in the pigment accumulation (Fig2, 4 and 6).

Table 1 - Activities of Isoutrate Dehydrogenase (ICDH), Succinate Dehydrogenase (SDH), $\alpha$ - Ketoglutarate Dehydrogenase ( $\alpha-\mathrm{KDH})$, Malate Dehydrogenase (MDH), NADH-Dehydrogenase and Cytochrome-C Oxidase in the cerebellar mitochondria of normal and experimental group of rats.

\begin{tabular}{|c|c|c|c|c|c|c|}
\hline \multirow[b]{2}{*}{ Parameters } & \multicolumn{2}{|c|}{ Young(6 Months) } & \multicolumn{2}{|c|}{ Middle aged (12 Months) } & \multicolumn{2}{|c|}{ Aged (18 Months) } \\
\hline & $\begin{array}{l}\text { Group-Ia } \\
\text { Control }\end{array}$ & $\begin{array}{c}\text { Group- } \\
\text { IbDeprenyl }\end{array}$ & $\begin{array}{c}\text { Group-IIa } \\
\text { Control }\end{array}$ & $\begin{array}{c}\text { Group- } \\
\text { IIbDeprenyl }\end{array}$ & $\begin{array}{c}\text { Group-IIIa } \\
\text { Control }\end{array}$ & $\begin{array}{c}\text { Group- } \\
\text { IIIbDeprenyl }\end{array}$ \\
\hline \multicolumn{7}{|l|}{$\begin{array}{l}\text { TCA cycle } \\
\text { enzymes }\end{array}$} \\
\hline ICDH & $830 \pm 60.59^{\mathrm{a}}$ & $855 \pm 62.41^{\mathrm{a}}$ & $675 \pm 49.27^{\mathrm{b}}$ & $760.2_{\mathrm{c}} \pm 55.49$ & $580 \pm 42.34^{d}$ & $682 \pm 49.78^{b}$ \\
\hline $\begin{array}{l}\text { SDH } \\
\alpha \text { KDH }\end{array}$ & $\begin{array}{l}35.2 \pm 2.56^{\mathrm{a}} \\
72.1 \pm 5.26^{\mathrm{a}}\end{array}$ & $\begin{array}{l}42.2 \pm 3.08^{b} \\
90.1 \pm 6.57^{b}\end{array}$ & $\begin{array}{c}22.2 \pm 1.62^{\mathrm{c}} \\
45 \pm 3.28^{\mathrm{c}}\end{array}$ & $\begin{array}{l}27.7 \pm 2.02^{\mathrm{e}} \\
61.8 \pm 4.51^{\mathrm{d}}\end{array}$ & $\begin{array}{l}18.8 \pm 1.37^{\mathrm{f}} \\
36.4 \pm 2.65^{\mathrm{e}}\end{array}$ & $\begin{array}{l}25 \pm 1.82^{g} \\
54.8 \pm 4.0^{f}\end{array}$ \\
\hline MDH & $371.2 \pm 27.08$ & $409 \pm 29.85^{b}$ & $272 \pm 19.85^{c}$ & $306.1 \pm 22.34$ & $198 \pm 14.45^{\mathrm{e}}$ & $280 \pm 20.44^{\mathrm{c}}$ \\
\hline \multicolumn{7}{|l|}{$\begin{array}{l}\text { Respiratory } \\
\text { Marker } \\
\text { Enzyme } \\
\end{array}$} \\
\hline $\begin{array}{l}\text { NADH - } \\
\text { dehydrogenase }\end{array}$ & $35.2 \pm 2.56^{\mathrm{a}}$ & $51.3 \pm 3.74^{b}$ & $24.8 \pm 1.81^{\mathrm{c}}$ & $32.5 \pm 2.37^{\mathrm{d}}$ & $20.1 \pm 1.46^{\mathrm{e}}$ & $28.4 \pm 2.07^{\mathrm{f}}$ \\
\hline $\begin{array}{l}\text { Cytochrome- } \\
\text { C-oxidase }\end{array}$ & $\begin{array}{c}4.0 \times 10^{2} \pm \\
0.29^{\mathrm{a}}\end{array}$ & $\begin{array}{c}5.01 \times 10^{2} \pm \\
0.36^{\mathrm{b}}\end{array}$ & $\begin{array}{c}3.2 \times 10^{2} \pm \\
0.23^{c}\end{array}$ & $\begin{array}{c}4.10 \times 10^{2} \pm \\
0.29^{\mathrm{a}}\end{array}$ & $\begin{array}{c}2.90 \times 10^{2} \pm \\
0.21^{\mathrm{d}}\end{array}$ & $\begin{array}{c}3.95 \times 10^{2} \pm \\
0.28^{\mathrm{a}}\end{array}$ \\
\hline
\end{tabular}

Results are mean \pm SD for six animals; one way ANOVA; Duncan's multiple comparison test. Values that have a different superscript letter $(\mathrm{a}, \mathrm{b}, \mathrm{c}, \mathrm{d})$ differ significantly $(\mathrm{P}<0.05)$ with each other.

Group Ib, IIb, IIIb, Deprenyl ,2 mg/kg body wt/day, i.p. for 15 days.

Values expressed: ICDH, nmol of $\alpha$-ketoglutarate formed/min per mg protein; $\alpha-\mathrm{KDH}$. nmol of ferrocyanide formed/min per mg protein; SDH, $\mu \mathrm{mol}$ of succinate oxidized/min per mg protein; $\mathrm{MDH}, \mu \mathrm{mol}$ of NADH oxidized/min per $\mathrm{mg}$ protein; NADH-dehydrogenase, $\mu \mathrm{mol}$ of $\mathrm{NADH}$ oxidized/min per $\mathrm{mg}$ protein; Cytochrome-c-oxidase, change in optical density/min per mg protein

Table 2 Purkinje neuronal area and accumulated pigment area of various groups.

\begin{tabular}{|l|l|l|l|}
\hline Groups & Neuronal area & Pigment area & \% pigment area \\
\hline Ia & $35403.5 \pm 0.66^{\mathrm{a}}$ & $751.33 \pm 0.23^{\mathrm{a}}$ & $2.10 \%$ \\
\hline Ib & $23658.5 \pm 0.73^{\mathrm{b}}$ & $548 \pm 0.63^{\mathrm{b}}$ & $2 \%$ \\
\hline IIa & $37892.33 \pm 0.80^{\mathrm{c}}$ & $4144 \pm 0.76^{\mathrm{c}}$ & $10.90 \%$ \\
\hline IIb & $40071.17 \pm 0.59^{\mathrm{d}}$ & $1189.5 \pm 0.64^{\mathrm{d}}$ & $2.90 \%$ \\
\hline IIIa & $34193.83 \pm 0.56^{\mathrm{e}}$ & $2947.83 \pm 0.60^{\mathrm{e}}$ & $8.60 \%$ \\
\hline IIIb & $31328.33 \pm 0.62^{\mathrm{f}}$ & $1409.5 \pm 0.43 \mathrm{f}$ & $4.50 \%$ \\
\hline
\end{tabular}

Treated groups, $2 \mathrm{mg} / \mathrm{kg}$ body wt/day, deprenyli.p. for 15 days. Results are mean $\pm \mathrm{SD}$ for six animals; one-way ANOVA; Duncan"es multiple comparison test. Values that have a different superscript letter (a, b, c, d, e, f) differ significantly $(\mathrm{p}<0.05)$ with each other. Values expressed: Area $\mu \mathrm{m}^{2}$ 


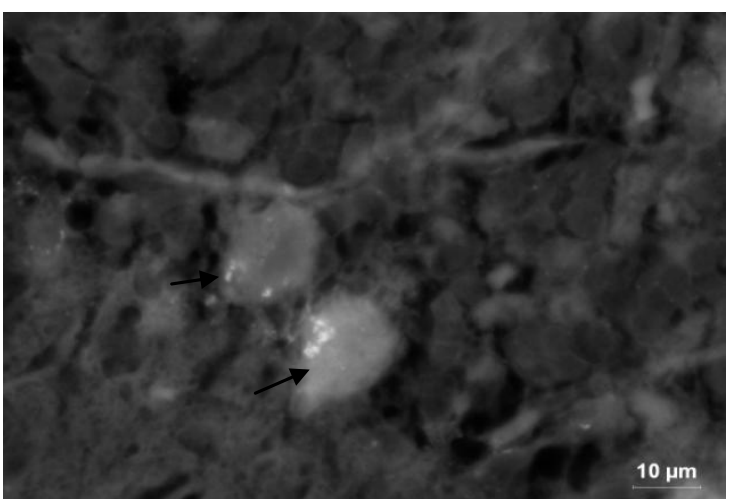

Fig 1 Fluorescent photomicrograph of the purkinje neurons from Group Ia of control rats. Note the presence of bluish white fluorescing lipofuscin granules (Arrows; 100x).

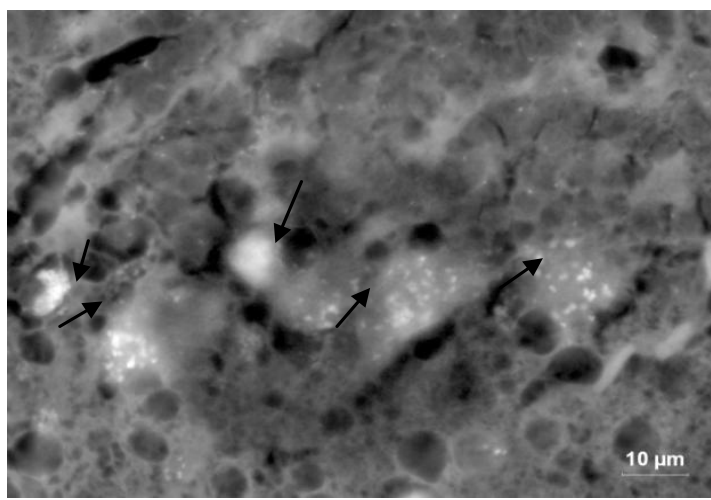

Fig 3 Fluorescent photomicrograph of the purkinje neurons from Group IIa of control rats showing the presence of pigment aggregation emitting golden-yellow refringence. Also note the presence of glial cells containing the pigment close by the neurons (Arrows; 100x).

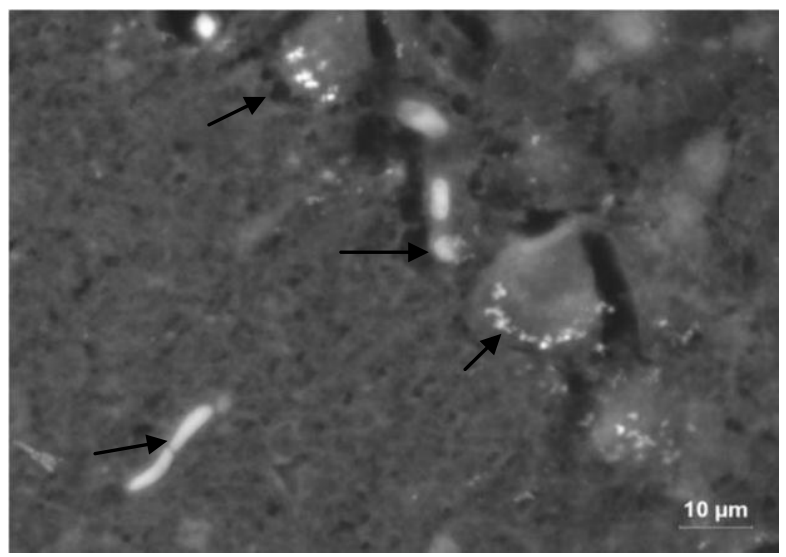

Fig 5 Fluorescent photomicrograph of the purkinje neurons from Group IIIa of control rat cerebellum showing blood capillaries laden with golden yellow pigment.Also note glial cells containing the pigment close by the neurons and purkinje neurons habouring huge clumps of golden-yellow fluorescing pigment.

(Arrows; 100x).

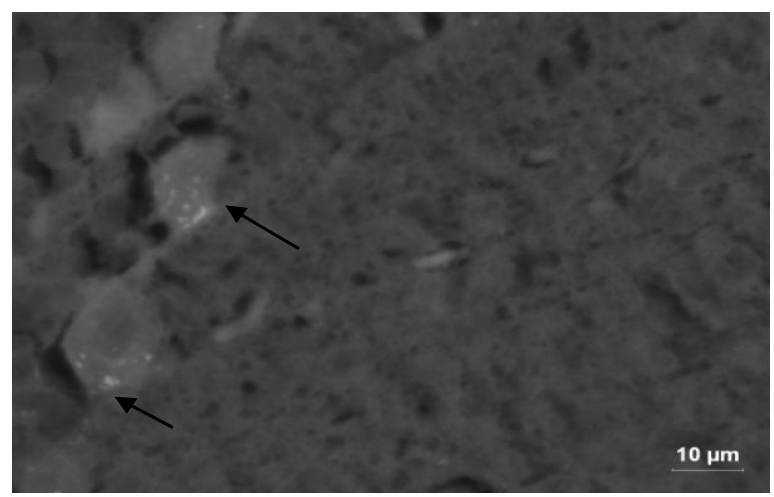

Fig 2 Fluorescent photomicrograph of the purkinje neurons from Group Ib of experimental rats showing less amount of pigment (Arrows; 100x).

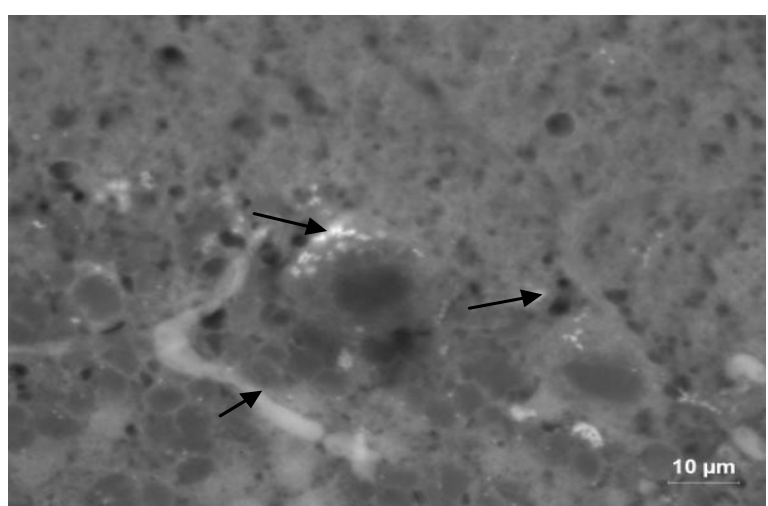

Fig 4 Fluorescent photomicrograph of the purkinje neurons from Group IIb of experimental rats showing less amount of pigment after deprenyl treatment. Note the loose texture of pigment duplexes in aggregates also showing the blood capillaries laden with golden yellow pigment (Arrows; 100x).

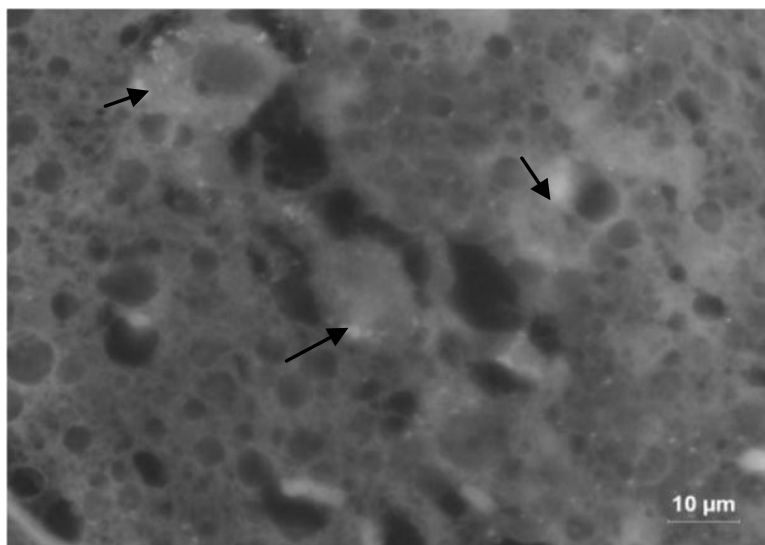

Fig 6 Fluorescent photomicrograph of the purkinje neurons from Group IIIb of experimental rats showing almost decrease of pigment after deprenyl treatment.

(Arrows; 100x). 


\section{Discussion}

Mitochondria provide energy for basic metabolic processes, produce oxidants as inevitable by products, and decay with age impairing cellular metabolism and leading to cellular decline. Mitochondrial membrane potential, respiratory control ratios, and cellular oxygen consumption decline with age, and oxidant production increases $[16,17,18]$. Likewise age-related changes in the central nervous system alter homeostatic mechanisms of the whole organism. The central nervous system requires a great quantity of energy for the transmission of impulses along the neural pathway; thus, functional mutilation of mitochondria results in neurodegeneration and loss of neuronal metabolic control.

In the present study, a significant decline was noticed in the activities of TCA cycle enzymes (isocitrate dehydrogenase, $\alpha$-ketoglutarate dehydrogenase, succinate dehydrogenase and malate dehydrogenase) and respiratory marker enzymes (NADH dehydrogenase and cytochrome-c-oxidase) in the cerebellum of aged control compared to that of young control. This suggested that the mitochondrial oxidative phosphorylation was operating at a lower level in aged rats despite the higher energy demand during aging. This present observation is in accordance with an earlier reported study [19]. NADH/NAD ratio has been reported to rise in the aged liver mitochondria due to prolonged metabolic overload on cells. This in turn may result in diminution in the activities of TCA enzymes by the mechanism of mass action, as observed in the present study. Furthermore free radicals generated during aging might have damaged the mitochondrial membrane and hence inactivated these enzymes as explained by Ithayarasi \& Shyamala Devi [20] and/or leaked into the cytoplasm and then into the blood stream. In contrast with all other enzymes of the TCA cycle, which are soluble proteins found in the mitochondrial matrix, succinate dehydrogenase is an integral membrane protein. It is tightly attached to the inner membrane and is directly linked to the electron transport, transferring electrons to the respiratory chain [21]. Succinate dehydrogenase is a site for metabolic control in TCA cycle [22] and contains many cysteine rich sulfur clusters and can be inhibited by agents that modify sulfhydryl groups.

The respiratory marker enzyme NADH dehydrogenase is located in the mitochondrial membrane [23]. A significant reduction in respiratory marker enzyme NADH dehydrogenase and cytochrome-c-oxidase was observed in the present study. During aging, decreased NADPH and NADH oxidation accelerates the inactivation of cyt-450 to cyt-p420 and is associated with destruction of nucleus, mitochondria and endoplasmic reticulum [24]. Alterations in the status of respiratory components, phosphorylative activity, cytochromecoxidase activity and hepatic adenylate charge level have been reported in age associated disorders [25]. The rate of mitochondrial superoxide anion radical $\left(\mathrm{O}_{2}^{-}\right)$and hydrogen peroxide $\left(\mathrm{H}_{2} \mathrm{O}_{2}\right)$ generation increases in the later part of life [26]. This, in turn, affects the balance between pro-oxidants and antioxidants in biological systems leading to modifications in vital biomolecules. Accumulation of these free radicals may also lead to increase of membrane damage and impair mitochondrial functions as well as ATP synthesis. Oxidative damage to mitochondria is a major cause of aging. Mitochondria are a potential target of injury by oxygen radicals, and an alteration in mitochondrial membrane function is an important component of oxidative stress in cells. Lipid peroxidation in vivo has been identified as a basic deteriorative reaction in the aging process [27, 28] and the free radicals produced as a result of this lipid peroxidation may attack the RNA polymerase encoding these antioxidant enzymes.

However, a significant increase was noticed in the activities of TCA cycle enzymes (isocitrate dehydrogenase, $\alpha$-ketoglutarate dehydrogenase, succinate dehydrogenase and malate dehydrogenase) and respiratory marker enzymes (NADH dehydrogenase and cytochrome-c-oxidase) in the cerebellum of treated rats. A mechanism that might explain the protective effect of Deprenyl can be construed by considering its chemical structure. Deprenyl is a propargylamine compound with a tertiary amino group and an acetylene group. It differs from the other propargylamine derivatives for the presence of a chiral carbon that gives the characteristics stereospecificity. Deprenyl can act in the same way as several other molecules having one or more amino groups able to inhibit the mitochondrial permeability transition (MPT) induced by dopamine oxidation in brain mitochondria [29]. This effect can be explained as an almost general inhibitory effect of these amines observed on most $\mathrm{K}^{+}$channels $[30,31,32]$. Most likely, the transition pore has preserved the structural features of the archetypal $\mathrm{K}^{+}$channel that permits interaction with amines, in this case with Deprenyl, resulting in MPT inhibition. The interaction of the monovalent cationic drug with critical amino acid residues present in the pore forming structures can be responsible for the observed inhibition. In this regard, Deprenyl can interact with the ring of aromatic residues by means of cation $\pi$ interactions [33] or with carboxylate ions by means of weak electrostatic interactions [34].

We observed that there was a significant $(P<0.05)$ decrease in steady-state of MDA levels in rats of Groups Ib, IIb and IIIb cerebellum treated with deprenyl. A previous study had also shown chronic deprenyl induced suppression of lipid peroxidation in rat striatum [35] and a recent study done by Kiray [36] elicited the LPO reduction with deprenyl. Since deprenyl can suppress $\mathrm{OH}^{*}$ radical formation, deprenyl ${ }^{\text {ee }}$ inhibition of lipid peroxidates could be due to its $\mathrm{OH}$ radical suppressing ability. Previous microscopic histological studies have 
shown that deprenyl decreased the age-related lipofuscin accumulation in the rat hippocampal pyramidal neurons and purkinje neurons of cerebellum [37]. Since lipidperoxides greatly contribute to the formation of lipofuscin [38] the deprenyl-induced decline in lipofuscin accumulation would appear to be the result of the deprenyl-induced reduction in lipid peroxides. It is also important that deprenyl lowers lipid peroxidation products in the thalamus where normal aging does not elevate lipid peroxidation [39]. Fluorescent microscopic analysis of lipofuscin and its quantification gives an additional support for the biochemical observations made in the present study.

In conclusion, the results of the present investigation indicate that deprenyl restores the age induced aberrations in the cerebellar mitochondrial energy status in rats by its ability to strengthen the neuronal membrane by its membrane stabilizing capacity and maintaining the activities of TCA cycle enzymes and respiratory marker enzymes at near normalcy and prevents age-associated diseases and thus, delays ageing.

\section{References}

[1]. Arivazhagan P, Ramanathan K and Panneerselvam C (2001). Effect of DL-alpha-lipoic acid on mitochondrial enzymes in aged rats. Chem. Biol. Interact. 138: 189-198.

[2]. Khaidakov M, Siegel ER, Shmookler Reis RJ (2006). Direct repeats in mitochondrial DNA and mammalian lifespan. Mech Ageing Dev127:808-812

[3]. Olgun A, Akman S, Serdar MA, Kutluay T (2002) Oxidative phosphorylation enzyme complexes in caloric restriction. ExpGerontol 37:639-645

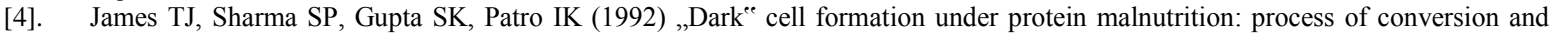
concept of ,semi-dark ${ }^{e c}$ type Purkinje cells. IndJrExptl Biol. 30: 470

[5]. Vohra1 BPS, James TJ, Sharma SP, Kansal VK, Chudhary A, Gupta SK (2002) Dark neurons in the ageing cerebellum: their mode of formation and effect of Maharishi AmritKalash. Biogerontology. 3: 347-354

[6]. Knoll J, Dallo J, Yen TT (1989) Striatal dopamine, sexual activity and lifespan longevity of rats treated with (-) Deprenyl. Life Sciences. 45:525-531

[7]. Magyar K, Palfi M, Tabi T, Kalasz H, Szende B, Szoko E (2004) Pharmacological aspects of (-)-Deprenyl. Curr. Medi. Chem. 11:2017-2031

[8]. Raz N, Gunning FM, Head D, Dupuis JH, McQuain J, Briggs SD (1997) Selective aging of the human cerebral cortex observed in vivo: differential vulnerability of the prefrontal gray matter. Cereb Cortex. 7:268-282.

[9]. Plummer D.T (1998). An introduction to practical biochemistry. Third Edition.McGrawHill Book Company (U. K) Limited. 268269.

[10]. Bell J.L and Baron D.N (1960). A colorimetric method for determination of Isocitate dehydrogenase. Clin. Chim. Acta. (5): 740 .

[11]. Slater E.C and Bonner W.D (1952). The effect of fluoride on succinic oxidase system. Biochem. J. (52): 185-196.

[12]. Mehler A.H, Korenberg A, Crisolia S and Ocho S (1948). The enzymatic mechanism of oxidation-reductions between malate or isocitrate or pyruvate. J. Biol. Chem. (174): 961977.

[13]. Minakami S, Ringler R.L and Singer T.P (1962). Studies on the respiratory chain-linked dihydrodiphosphopyridine nucleotide dehydrogenase. I. Assay of the enzyme in particulate and in soluble preparations. J. Biol. Chem. (237): 569-576.

[14]. Reed L.J and Mukherjee R.B (1969). Methods Enzymol. (13): 53.

[15]. Pearl W, Cancercao J and Zweifach BW (1963). Microdetermination of cytochrome oxidase in rat tissues by the oxidation of Nphenyl-p-phenylenediamine or ascorbic acid. J. Histochem. Cytochem., 11, 102-107.

[16]. Shigenaga MK, Hagen TM, Ames BN (1994) Oxidative damage and mitochondrial decay in aging. ProcNatlAcadSci USA 91:10771-10778

[17]. Harman D (1972) The biologic clock: the mitochondria? J Am GeriatrSoc 20:145-147

[18]. Hagen TM, Ingersoll RT, Wehr CM, Lykkesfeldt J, VinarskyV,Bartholomew JC, Song

[19]. MH, Ames BN (1998) Acetyl-L-carnitine fed to old rats partially restores mitochondrial function and ambulatory activity. ProcNatlAcadSci USA 95:9562-9566

[20]. Sastre J, Pallardo FV, García de la Asuncion J and Vina J (2000). Mitochondria, oxidative stress and aging. Free Radic. Res. (32): $189-198$.

[21]. Ithayarasi A.P and Shyamala Devi C (1998). Effect of alpha-tocopherol on mitochondrial electron transport in experimental myocardial infarction in rats. Indian J. Biochem. Biophys.

[22]. (35): 115-119.

[23]. Singh U.K, Agarwal K.N and Shankar R (1990). Effect of under nutrition on succinate dehydrogenase and acetylcholine esterase in developing rat brain. Ind. J. Exp. Biol. (28): 868870.

[24]. Papa S, Lofrumento N.E, Paradies G and Quagliariello E (1969). Mechanism of inhibition by uncouples of succinate oxidation in isolated mitochondria. Biochim. Biophys. Acta.(180): 35-44.

[25]. Nicolay K, van der Neut R, Fok J.J and de Kruijff B (1985). Effects of adriamycin on lipid polymorphism in cardiolipin-containing model and mitochondrial membranes. Biochim.Biophys. Acta. (819): 55-65.

[26]. Sohal R.S, Arnold L. A and Sohal B.H. (1990) Age-related changes in antioxidant enzymes and prooxidant generation in tissues of the rat with special reference to parameters in two insect species. Free Radic. Biol. Med. (10): 495-500.

[27]. Yarian C.S, Toroser D and Sohal R.S (2006). Aconitase is the main functional target of aging in the citric acid cycle of kidney mitochondria from mice. Mech. Ageing Dev. (127): 79-84.

[28]. 26. Wei Y.H, Kao S.H and Lee H.S (1996). "Simultaneousincrease of mitochodndrial DNA deletions and lipid peroxidation in human aging". Ann. N.Y. Acad. Sci. (786): 24-43.

[29]. Barnett Y.A and King C.M (1995). An investigation of antioxidant status, DNA repair capacity and mutation as function of age in humans. Mutat. Res. (338): 115-128.

[30]. Ames B. N, Shigenaga M. K, Hagen T. M. (1993). Oxidants, antioxidants, and the degenerative diseases of aging. Proc. Natl. Acad. Sci. USA 90: 7915-7922.

[31]. Lee C.S, Lee CS, Ko H H, Song J H, Han E S (2002). Effect of R-(-)-deprenyl and harmaline on dopamine and peroxynitriteinduced membrane permeability transition in brain mitochondria. Neurochem Res 27(3): 215-224.

[32]. Liepins A, LeFever A, Truitt R.L (1989). Serotonin modulated $\mathrm{Ca}^{2+}$ dependent $\mathrm{K}^{+}$channels in alloimmune effector cell lytic function. ImmunopharmacolImmunotoxicol (11): 165-78. 
[33]. Pearson W.L and Nichols C.G. (1998). Block of the Kir2.1 channel pore by alkylamine analogues of endogenous polyamines. $J$ Gen Physiol (112); 351- 63.

[34]. Weiger T and Hermann A. (1994). Polamines block $\mathrm{Ca}^{2+}$ activated $\mathrm{K}^{+}$channels in pituitary tumor cells (GH3). J MenbrBiol (140): $133-42$.

[35]. Dougherty D.A. (1996). Cation $\pi$ interactions in chemistry and biology: a new view of benzene, Phe, Tyr and Trp. Science (271): 163-8.

[36]. Yamada M, Kurachi Y (1995). Spermine gates inward-rectifying muscarinic but not ATP-sensitive $\mathrm{K}^{+}$channels in rabbit atrial mycocytes. Intra cellular substances-mediated mechanism of inward rectification. J BiolChem; (270): 9289-94.

[37]. Wu R.M, Murphy D.L and Chiueh C.C (1996). Suppression of hydroxyl radical formation and protection of nigral neurons by 1deprenyl (Selegiline). Annals N Y AcadSci (786): 379-390.

[38]. Kiray M, Bagriyanik H.A, Pekcetin C, Ergur B.U, Uysal N, Ozyurt D, Buldan Z. (2005). Deprenyl and the relationship between its effects on spatial memory, oxidant stress and hippocampal neuronsin aged male rats. Physiol Res: 205-211.

[39]. Amenta A, Stefano Bongranib, SandroCadelb, Fabio Ferrantec, Bruno Valsecchib and Yong-Chun Zenga(1994). Influence of treatment with 1-deprenyl on the structure of the cerebellar cortex of aged rats. Mech Ageing and Dev. (75)2: 157-167

[40]. Fletcher B.L, Dillard C.J, Tappel A.L (1973). Measurement of fluorescent lipid peroxidation products in biological systems and tissues. AnalytBiochem (52). 1

[41]. Kaur J, Sharma D, Singh R (2001). Acetyl-L-carnitine enhances $\mathrm{Na}^{+} \mathrm{K}^{+}$- ATPase glutathione-S-transferase and multiple unit activity and reduces lipid peroxidation and lipofuscin concentration in aged rat brain regions. Neurosci. Lett. (301): 1-4. 